\title{
PHENOMENOLOGICAL APPROACH OF OUT-OF-FIELD TEACHING: CHALLENGES AND OPPORTUNITIES
}

\author{
Ivan E. Arendain ${ }^{1}$, Marilou Y. Limpot ${ }^{2}$ \\ ${ }^{1}$ Master of Arts in Filipino, Professional Schools, University of Mindanao, Digos City, Philippines \\ ${ }^{2}$ Doctor of Education, Professor, University of Mindanao, Davao City, Philippines
}

Article DOI: https://doi.org/10.36713/epra9379

DOI No: 10.36713/epra9379

\begin{abstract}
The goal of this study was to learn about the challenges and opportunities faced by out-of-field teachers in a public and private school in Davao del Sur. A phenomenological qualitative research design was used in this study. The information was collected from nine (9) out-of-field teachers in the province of Davao del Sur. On the other hand, data was gathered through an in-depth interview with the participants. The result revealed that the out-of-field teachers had diverse experiences, such as: assuring that they review the topic before teaching it, challenges of first time out-of-field teachers, challenges, and struggles of choosing the right teaching strategy, challenges of having meaningful learning content, studying and searching for the learning content, peer tutoring with co-teacher, use of English language for effective teaching, use of suitable teaching strategies, difficult but you have to endeavor, being resourceful and optimistic in teaching and it gives additional knowledge. Furthermore, results show that out-of-field teaching is a challenge for a teacher. On the other hand, teaching-out-field subjects won't make you less of a teacher. Instead, this opportunity will widen your knowledge towards other subject matter as well as your pedagogical knowledge as a teacher.

KEYWORDS: out-of-field, out-of-field teacher, out-of-field teaching, challenges, opportunities, phenomenological research, Philippines
\end{abstract}

\section{INTRODUCTION}

A teacher's knowledge of the subject matter is the heart of his or her teaching career (Breen et al., 2018). An effective teacher must have a vast knowledge of the subject matter that he/she teach. However, what if a teacher teaches a subject that he has not even mastered? In the study of du Plessis (2017), she confirmed that out-of-field teaching is widespread and affects teachers' teaching efficacy. In addition, teachers teaching unspecialized subjects tend to have low self-esteem (du Plessis, 2019).

Teaching unspecialized subjects is rampant worldwide (du Plessis, 2015). In the study conducted at West Australia, they found out that in the year 2007-2008, 28\% of teachers taught subject matter that was not related to their specialization (Weldon, 2016). Moreover, a workforce report in Australia found that $39 \%$ of principals inside the city and between $42 \%$ and $66 \%$ of principals outside the city struggle to look for applicants and placement difficulties.

On the other hand, in South Africa, a major issue is the inconsistency of new teacher qualifications and specializations. Their educational institution requires teachers who can effectively teach language and mathematics (Hofmeyer, 2015). Meanwhile, due to the worsening problem of out-offield teaching in Korea, it is difficult for them to deliver quality teaching to their students. Students are frequently taught by teachers who are unqualified or have a limited understanding of the subject. According to the statistical analysis, there are 1,410 secondary teachers in the sample across the country, and out-of-field teaching is common in Korea, which requires prompt action to address the worsening situation (Kwak, 2019).

Three theories support this research. The first is Edwards, Caplan, and Van Harrison's PersonEnvironment Fit Theory. According to this theory, workers will be more productive if their qualifications and abilities are matched to the work they are doing (Kristof-Brown, \& Guay, 2011). The Social Constructivist Theory of Lev Vygotsky is the second. This theory focuses on the effect of what Vygotsky refers to as "more knowledgeable others," or those who are knowledgeable enough to provide guidance and information. Finally, Albert Bandura's self-efficacy theory (2010). Bandura \& Adams 1997; 
Türkolu et al. 2017 define self-efficacy as a person's belief in his or her capacity to perform a task assigned to them. These theories prompted me to investigate the influence and impact of teachers teaching students in disciplines in which they were not proficient.

Out-of-field teaching is also common in the Philippines, and teachers have challenges when teaching a subject they do not mastered (Bayani \& Guhao, 2017. On the other hand, our country today faces a teacher shortage as a result of the Department of Education's K-12 program. Approximately 60,000 teachers are required to address the country's teacher deficit (Asian Development Bank, 2014). Bayani and Guhao (2017) stated that this program implemented by the Department of Education is one of the reasons for the worsening of the problem of out-of-field teaching in the country. Teaching a low-skilled topic can have a negative impact on a teacher's psychological well-being, which can hinder his students' learning and teaching (Akram et al., 2017). Out-of-field teaching is a problem that needs to be addressed for the professional development of teachers, particularly those who teach nonspecialized subjects. This research will focus on the challenges and opportunities that teachers face when teaching a subject that they are unfamiliar with. The phenomenon of out-of-field teaching has received less research. As a researcher, I have yet to find research regarding BSED Filipino graduate teachers teaching a subject they have not mastered. This has been my motivation for this study to be conducted immediately, which will help our teachers, especially the teachers who teach the subject they have not mastered.

\section{OBJECTIVES}

This research aims to discover the challenges and opportunities faced by teachers experiencing out-of-field teaching.

\section{METHODS}

A qualitative-phenomenological design was adopted in the study. It highlights people's unique experiences and focuses on their perceptions (Gerring, 2017).

The researcher searched for nine (9) BSED Filipino graduates who were teaching a subject they have not mastered. Teachers chosen as participants may work in both public and private schools in Region XI. However, to ensure the learning limit, the researcher should only include BSED Filipino graduate teachers who teach secondary from 2020 to 2021, rather than only BSED Filipino graduate teachers who teach Elementary.

A purposive sample strategy was adopted in this study. Purposeful sampling is a qualitative research technique developed by Palinkas et al. (2015) to find and select available information from cases with limited data sources.

The researcher used interview guide questions in his interview with the participants. Through the interview guide questions, there will be unity of the questions used by all the interviewees. In addition, this instrument is essential so that the researcher will not forget in the interview.

With the effect of UMERC approval 202176 , this research was conducted in private and public schools in the province of Davao del Sur. The selected participants in this research are teachers who have graduated from BSED Filipino and teach a subject they have not mastered in the school year 2020-2021.

The researcher conducted in-depth interviews with nine (9) participants to determine their experience in teaching the subject they had not mastered. Additionally, the researcher will use KII or Key Informant Interview to obtain this study's data. Before interviewing with the participants, they will first be shown the consent letter to inform the purpose of the research.

The data collected from out-of-field teachers were analyzed using thematic analysis. According to Braun and Clarke (2014), thematic analysis is a foundational method of analysis that uses interpretation and description to examine the relevance of the cohesive learning and the theme that can be applied to the data.

\section{RESULTS AND DISCUSSIONS}

Table 1

The formulated theme and central ideas on the experiences of out-of-field teachers.

\begin{tabular}{|l|l|}
\hline \multicolumn{1}{|c|}{ Themes } & \multicolumn{1}{c|}{ Central Ideas } \\
\hline $\begin{array}{l}\text { Assuring that they review the topic } \\
\text { before teaching it }\end{array}$ & $\begin{array}{l}\text { It is challenging for the teacher to teach an unmastered subject, and } \\
\text { therefore, you need to study the lesson thoroughly. }\end{array}$ \\
\hline $\begin{array}{l}\text { Challenges of first time out-of-field } \\
\text { teachers }\end{array}$ & $\begin{array}{l}\text { In the beginning, there was difficulty with the teachers teaching the } \\
\text { subject they did not master. }\end{array}$ \\
\hline $\begin{array}{l}\text { Challenges, and struggles of choosing } \\
\text { the right teaching strategy }\end{array}$ & $\begin{array}{l}\text { One challenge that has given teachers concern is the difficulty in } \\
\text { developing effective strategies for teaching. }\end{array}$ \\
\hline $\begin{array}{l}\text { Challenges of having meaningful } \\
\text { learning content }\end{array}$ & $\begin{array}{l}\text { Having teachers fear that the content they will teach is not } \\
\text { meaningful. }\end{array}$ \\
\hline
\end{tabular}




\section{Experiences of Out-of-Field Teachers}

From the data collected, four (4) themes emerged: (1) assuring that they review the topic before teaching it, (2) challenges of first time out-offield teachers, (3) challenges, and struggles of choosing the right teaching strategy, and (4) challenges of having meaningful learning content.

\section{Assuring that they review the topic before teaching it}

In teaching, a teacher must have sufficient preparation before teaching a concept or a lesson. Lack of content knowledge is a challenge in teaching a subject (Kim et al., 2018). In this research, out-offield teachers are initially found to be unsatisfactory in teaching, and they spend much time studying a lesson (KII1,KII4,KII6 at KII8). Out-of-field teachers spend much time preparing the lesson they are going to teach (Ramli et al., 2017). In addition, they still need to understand the structure of a lesson, especially the unfamiliar contents of a subject (Ramli et al., 2017; Nixon et al., 2017).

\section{Challenges of first time out-of-field teachers}

This research shows that teachers who teach a subject they have not mastered have difficulty at first. This was confirmed in the study by Napier et al. (2020), who revealed that out-of-field teachers are having difficulty in their first year in the way they teach. In addition, the teacher knows the limit of his knowledge in the subject being taught (Kola, \& Sunday, 2015). Nixon et al. agreed (2017), teachers do not have a good experience in teaching the subject they have not mastered because they have to study it thoroughly before teaching it to the students, and it also causes them to lose the will to teach.

\section{Challenges, and struggles of choosing the right teaching strategy}

Research has shown that teachers who teach non -specialized subjects find it difficult to use appropriate teaching strategies. A teacher's lack of a good teaching strategy affects his or her lower selfesteem and self-efficacy (Hobbs, 2013; du Plessis, 2020). According to Sharplin (2014), out-of-field teachers feel a sense of innovation in the subject to be taught, which has become a barrier to using their ability. This is confirmed by the theory of selfefficacy (self-efficacy). Some of the factors why teachers feel out-of-field are self-efficacy and the commitment to teaching the subject not mastered (Kenny et al., 2020).

\section{Challenges of having meaningful learning content}

It was discovered in this research that teachers who teach a non -specialized subject face a challenge in finding meaningful lesson content (KII1, KII2, KII3, and KII4). This is in line with the statement of du Plessis (2019); teachers who teach a subject they have not mastered are afraid that the knowledge they share with students is not enough to affect their future. In addition, a teacher needs to be proficient in the subject he or she will teach for good quality teaching and education. In the 21 st century, it is expected that all professionals will be highly skilled in their field and be able to demonstrate excellence in their specialization (Cinkir \& Kurum, 2015).

Table 2

The formulated themes and central ideas on coping mechanism of out-of-field teachers

\begin{tabular}{|l|l|}
\hline \multicolumn{1}{|c|}{ Themes } & \multicolumn{1}{c|}{ Central Ideas } \\
\hline Studying and searching for the learning content & $\begin{array}{l}\text { Alocating time to research and study the content to } \\
\text { teach students. }\end{array}$ \\
\hline Peer tutoring with co-teacher & $\begin{array}{l}\text { Seek help from teachers who have sufficient } \\
\text { knowledge of the subject to be taught. }\end{array}$ \\
\hline Use of English language for effective teaching & Uses English in teaching to make teaching effective. \\
\hline Use of suitable teaching strategies & $\begin{array}{l}\text { Using appropriate and effective teaching strategies to } \\
\text { easily capture students' attention and have meaningful } \\
\text { learning. }\end{array}$ \\
\hline
\end{tabular}

\section{Coping mechanism of out-of-field teachers}

From the data collected, four (4) themes emerged: (1) studying and searching for the learning content, (2) peer tutoring with co-teacher, (3) use of English language for effective teaching,and (4) use of suitable teaching strategies.

\section{Studying and searching for the learning content}

Out-of-field teachers take the time to research valid information in the subject they will teach (KII1, KII2, KII3, KII4, KII5, KII6, KII7, KII8, and KII9). According to Ingersoll et al. (yr), students 'learning is the first consideration and goal of a teacher for effective teaching and learning. To do 
this, the identity of the teachers must be clear. It suggests that shaping teacher identity is necessary for teachers teaching a subject they have not mastered. Out-of-field teachers are confident that they have conveyed the knowledge that students need (Kenny et al.,2020).

\section{Peer tutoring with co-teacher}

No one is the monopoly of knowledge. The teacher teaching a subject they have not mastered makes a way to overcome the challenges they face by seeking help from their fellow teachers who are knowledgeable in a specific subject (KII3, KII4, KII7, KII8, and KII9). In fact, in the study of Gillies (2019), having collaborated with fellow teachers in teaching was of great help. Teachers work together when they collaborate and share their knowledge with other teachers, and on the other hand, they correct the wrong teaching methods. Stigmar (2016), that having a teacher-to-teacher collaboration is helpful in learning and teaching. In Lev Vygotsky's theory of Social Constructivism (1978), the importance of having people with sufficient knowledge (MKO) in an object to be guided and assisted with the knowledge needs has been explained.

\section{Use of English language for effective teaching}

Language is the main instrument to convey the essential knowledge that students need. This research shows that out-of-field teachers loved to use English as a medium of instruction and communication (KII6, and KII7). The result is in line with the study of Haidar \& Fang (2019), the use of English in teaching helps to understand better the relationship and difficulty of concept in the study of language and use its. Moreover, the second language also helps develop various teaching strategies in the curriculum (Leung, 2016).

\section{Use of suitable teaching strategies}

In the teaching and learning process it needs to develop appropriate strategies that will be used to make the teaching and learning of the students meaningful. This research suggests that out-of-field teachers think of meaningful and appropriate teaching strategies (KII1, KII6, and KII7). According to Nuangchalerm (2020), having an appropriate teacher strategy in his teaching is important so that he can share the knowledge that students need to know in the 21 st century.

Table 3

The formulated themes and central ideas on the insights of out-of-field teachers

\begin{tabular}{|l|l|}
\hline \multicolumn{1}{|c|}{ Themes } & \multicolumn{1}{c|}{ Central Ideas } \\
\hline Difficult but you have to endeavor & \\
\hline Being resourceful and optimistic in teaching & \\
\hline It gives additional knowledge. & \\
\hline Insights of out-of-field teachers &
\end{tabular}

From the collected three (3) themes emerged : (1) difficult but you have to endeavor, (2)

\section{Difficult but you have to endeavor}

Study shows that they do everything to fulfill the role of a teacher even if they have not mastered the subject they are teaching (KII1, KII2, KII3, KII6, and KII9). This is supported by the study of Hobbs (2013), love of profession makes the way to learn and thrive in teaching. Moreover, the creativity of out-of-field teachers helps to be effective teachers (Bayani \& Guhao, 2017).

\section{Being resourceful and optimistic in teaching}

It is clear from this research that teachers who teach a subject they have not mastered develop a cheerful disposition in life and become resourceful as a teacher (KII1, KII2, KII5, KII6, and KII9). Proof of this is the study of Kenny et al. (2020), teachers continuing their professional development need to identify what needs to change and identify what they do not yet know needs to know more. being resourceful and optimistic in teaching, and (3) it gives additional knowledge.

\section{It gives additional knowledge.}

This research found that teachers who teach a subject they have not mastered gain more knowledge, especially in the subject they teach (KII4, KII5, KII6, KII7, and KII8). Du Plessis(2020), agreed, teachers in out-of-field subjects are also interested in their teaching. They also see the opportunity to gain new knowledge and believe that teaching a subject not mastered can help their future as a teacher.

\section{CONCLUSION}

Teaching is both a difficult and rewarding profession. Teaching an unmastered subject, according to this research, is a challenging task for a teacher. On the other hand, teaching a subject that you do not master does not make you a bad teacher. Instead, it's an opportunity to deepen your understanding of a particular subject as well as your pedagogical knowledge as a teacher. 


\section{REFERENCES}

1. Asian Development Bank (2014). Republic of the Philippines: Teach for the

2. Philippines. Retrieved April 8, 2020, from the Asian Development Bank website: https://www.adb.org/sites/default/files/projectdocument/81738/47261-001-tar.pdf

3. Akram, M., Ilgan, A., \& Ozu, O. (2017). Quality of school work life of public school teachers: Cases from Turkey and Pakistan. Journal of Education and Educational Development, 4(2).

4. Bandura, A. (2010). Self-efficacy-Bandura. The Corsini encyclopedia of psychology, 1-3.

5. Bandura, A., \& Adams, N. E. (1977). Analysis of self-efficacy theory of behavioral change. Cognitive therapy and research, 1(4), 287-310.

6. Bayani, R. T., \& Guhao Jr, E. S. (2017). Out-offield teaching: Experiences of non-Filipino majors. International

Education, 5(11), 91-127.

7. Breen, S., Meehan, M., O'Shea, A., \& Rowland, T. (2018, April). An analysis of university mathematics teaching using the Knowledge Quartet. In INDRUM 2018.

8. Braun, V., \& Clarke, V. (2014). What can "thematic analysis" offer health and wellbeing researchers?. International journal of qualitative studies on health and well-being, 9(1), 26152.

9. Cinkir, S., \& Kurum, G. (2015). Discrepancy in Teacher Employment: The Problem of Out-ofField Teacher Employment. Educational Planning, 22(1), 29-47.

10. du Plessis, A. E. (2015). Effective education: Conceptualising the meaning of out-of-field teaching practices for teachers, teacher quality and school leaders. International Journal of Educational Research, 72, 89-102.

11. Du Plessis, A. E. (2017). Out-of-field teaching practices: What educational leaders need to know. Springer.

12. Du Plessis, A. E. (2019). Professional support beyond initial teacher education.

13. Du Plessis, A. E. (2020). The Wider School Community, the Out-of-Field Phenomenon and Education Improvement Policies. In Out-of-Field Teaching and Education Policy (pp. 267-286). Springer, Singapore.

14. Gerring, J. (2017). Qualitative methods. Annual Review of Political Science, 20, 15-36.

15. Gillies, R. M. (2019). Promoting academically productive student dialogue during collaborative learning. International Journal of Educational Research, 97, 200-209.

16. Haidar, S., \& Fang, F. (2019). English language in education and globalization: A comparative analysis of the role of English in Pakistan and China. Asia Pacific Journal of Education, 39(2), 165-176.

17. Hobbs, L. (2013). Teaching 'out-of-field'as a boundary-crossing event: Factors shaping teacher identity. International journal of science and mathematics education, 11(2), 271-297.
18. Hofmeyer, J. (2015). Teachers in South Africa: Supply and Demand 2013-2025.

19. Kenny, J., Hobbs, L., \& Whannell, R. (2020). Designing professional development for teachers teaching out-of-field. Professional development in education, 46(3), 500-515.

20. Kim, I., Ward, P., Sinelnikov, O., Ko, B., Iserbyt, P., Li, W., \& Curtner-Smith, M. (2018). The influence of content knowledge on pedagogical content knowledge: An evidence-based practice for physical education. Journal of Teaching in Physical Education, 37(2), 133-143.

21. Kola, A. J., \& Sunday, O. S. (2015). A review of teacher self-efficacy, pedagogical content knowledge (PCK) and out-of-field teaching: Focussing on Nigerian teachers. International Journal of Elementary Education, 4(3), 80-85.

22. Kristof-Brown, A., \& Guay, R. P. (2011). Person-environment fit. In S. Zedeck (Ed.), APA handbook of industrial and organizational psychology, Vol. 3. Maintaining, expanding, and contracting the organization (pp. 3-50). American Psychological Association.

23. Kwak, Y. (2019). Secondary school science teacher education and quality control in Korea based on the teacher qualifications and the teacher employment test in Korea. Asia-Pacific Science Education, 5(1), 1-14.

24. Leung, C. (2016). English as an additional language-a genealogy of language-in-education policies and reflections on research trajectories. Language and Education, 30(2), 158-174.

25. Napier, J. B., Luft, J. A., \& Singh, H. (2020). In the classrooms of newly hired secondary science teachers: The consequences of teaching in-field or out-of-field. Journal of Science Teacher Education, 31(7), 802-820.

26. Nixon, R. S., Luft, J. A., \& Ross, R. J. (2017). Prevalence and predictors of out-of-field teaching in the first five years. Journal of Research in Science Teaching, 54(9), 1197-1218.

27. Nuangchalerm, P. (2020). TPACK in ASEAN Perspectives: Case Study on Thai Pre-Service Teacher. International Journal of Evaluation and Research in Education, 9(4), 993-999.

28. Palinkas, L. A., Horwitz, S. M., Green, C. A., Wisdom, J. P., Duan, N., \& Hoagwood, K. (2015). Purposeful sampling for qualitative data collection and analysis in mixed method implementation research. Administration and policy in mental health and mental health services research, 42(5), 533-544.

29. Ramli, A. A., Ibrahim, N. H., Surif, J., Bunyamin, M. A. H., Jamaluddin, R., \& Abdullah, N. (2017). Teachers' readiness in teaching stem education. Man in India, 97(13), 343-350.

30. Sharplin, E. D. (2014). Reconceptualising out-offield teaching: Experiences of rural teachers in Western Australia. Educational Research, 56(1), 97-110. 
31. Stigmar, M. (2016). Peer-to-peer teaching in higher education: A critical literature review. Mentoring \& Tutoring: partnership in learning, 24(2), 124-136.

32. Türkoglu, M. E., Cansoy, R., \& Parlar, H. (2017). Examining Relationship between Teachers' Self-Efficacy and Job Satisfaction. Universal Journal of Educational Research, 5(5), 765-772.

Vygotsky, L. S. (1978). Mind in Society: The Development of Higher Psychological Processes (Revised ed.). Harvard Univ Pr.

33. Weldon, P. R. (2016). Out-of-field teaching in Australian secondary schools. 